\title{
The Core of Resistance: Recognising Intersectional Struggle in the Kurdish Women's Movement
}

\author{
Bruna Ferreira* \\ Vinícius Santiago**
}

\begin{abstract}
The paper addresses the women's movement in the Northern Syrian region known by Kurds as Rojava, a movement whose central role in building an autonomous political project has its roots in the Kurdish nationalist struggle, specifically that organised by the Kurdish Worker's Party, also known as the PKK, in Turkey. This study brings to the fore reflections on the power relations that cross the struggle carried out by these women, who, for their part, are crossed by the intersection of gender, ethnicity and class, which feeds and composes the critical praxis of this organised struggle. The Kurdish women's political path is approached through the contradictions and ambiguities they encounter when they face the challenge of becoming aware of their own place in a political project, which at first had a nationalist character and is now beginning to gain new contours. The presence of the female figure in a political context of armed conflict endows these women with the role of challenging the boundaries on which the foundational elements of international politics rely, namely, the boundary between public and private spheres and gender roles played socially and politically. The Kurdish women's movement in Rojava disturbs the foundational boundaries of the modern nation-state alongside the hegemonic constructions of masculinity and femininity, and the militarised character of politics, which are constitutive of the modern imaginary of political community.
\end{abstract}

Keywords: Intersectionality; Kurdish Women; Rojava; Nation-state; Movement.

\section{Introduction}

Many magazine and newspaper articles that address the struggle waged by Kurdish women taking up arms to fight the terrorist group Daesh, in the Democratic Federation of Northern Syria (DFNS), are marked by power relations underlying gender differences.

\footnotetext{
* State University of Rio de Janeiro (UERJ), Rio de Janeiro-RJ, Brazil; brunafbrito2@gmail.com. ORCID iD 0000-0002-2444-7427.

** Pontifical Catholic University of Rio de Janeiro (PUC-Rio), Rio de Janeiro-RJ, Brazil; viniciuswbsantiago@ gmail.com. ORCID iD 0000-0002-7328-9461.
} 
They highlight these women's beauty, their long, braided hair and coloured scarves in the battlefield, making their political discussions invisible. Moreover, the challenges imposed when their female bodies are in these places of confrontation are deliberately left behind. This kind of media coverage ${ }^{1}$ brings out the astonishment common to a certain negotiation with the East (Said 1991), as long as it is the women from this part of the world who dare to engage in such a masculine activity, namely, militarism.

The role of Kurdish women in the region known as Rojava ${ }^{2}$ in the DFNS is deeply rooted in a historical context within which they participated actively, that is, in the development of important nationalist organisations such as the Kurdistan Workers' Party, known as PKK, in Turkey. Due to the historical experiences and learning processes shared between Kurdish nationalist organisations in Turkey and in Syria, ${ }^{3}$ the Kurdish women's current organisation in the DFNS is regarded as the product of a gradual bloom crossed by a set of confrontations they have faced.

In this article, we argue that the Kurdish women's struggle, emerging from a context with interconnected systems of oppression, creates incentives to the formation of women's autonomous organisations. Thereby, it also challenges the hegemonic social constructions of masculinity and femininity, the boundary between public and private spheres, and the sexual division implied in it, as well as the militarised character of politics. All of these are constitutive elements of the modern imaginary of political community. The theoretical framework used in this article has intersectional feminism as a point of departure, referring to authors such as Patricia Hill Collins and Nira Yuval-Davis, who write on the power structures that sustain social divisions related to gender, race and class. Furthermore, the discussion relies upon readings from feminists such as Carole Pateman, Wendy Brown and Cynthia Enloe on the implications of the role played out by women as disruptive actors on the foundational boundaries of international politics. This article arises from a question made from the observation of a social phenomenon, that is the strength of Kurdish women's autonomous organisation in the DFNS. Such inquiry is motivated by theoretical questions connected to intersectionality and critical approaches to national phenomena, as mentioned earlier. Therefore, this is a discussion article.

Through these theoretical lenses, we aim to open up ways to map how the Kurdish women's movement, embedded in its contradictions and ambiguities and crossed by the intersections of power relations, offers some background to overcoming the traditional role and site to which women have been historically been assigned within modern political theory. Moreover, following Mary Ann Tetrault's political insights, we draw attention to the implication of women working on revolutionary projects which target the genderbased foundation of nation-states, and also the political gains arising from these women's political engagement. As claimed by Nira Yuval-Davis, working on such projects creates the possibility of forging new identities that are not based on a hierarchical and patriarchal political community design.

In order to encompass such discussions, the paper is organised into three sections. The first one deals with the encounter of Kurdish women with nationalism in Turkey, reflecting on the confrontations that occur in this context. At the same time, some data is 
available to contribute to the debate on the vulnerability of Kurdish women and Kurdish population in Turkey. The second section deals with the context that creates the possibility of the current political project in the DFNS, reflecting, without the intention of exhausting the discussion, on the general lines of Democratic Confederalism. The final section deals with the encounter of Kurdish women who were part of PKK with their male Party fellows, addressing the contradictions of the relations established in this encounter.

\section{The encounter with nationalism}

Women's relationship with the nation-state has been quite difficult. While women take a strategic stance on nationalism, as has historically been the case, it is through the instrumentalisation of ideas about masculinity and femininity, as Enloe (2014) argues, in such a way that women do not occupy the position of active actors in the politics of the nation and do not effectively challenge the political privilege of men. Although women are transformed into national symbols, in such processes they are not considered genuine actors who contribute with their own ideas, debates and skills (Enloe 2014: 87). This results in what the author calls 'patriarchal nationalism' (Enloe 2014: 12), a phenomenon responsible for creating the arrangement of world politics in the last two centuries which states that the forces that oppress and marginalise women are external, never internal, restating the old nationalist division of 'us' and 'them.'

The founding of the Turkish Republic in 1923 created a conscious political project of secularisation in addition to the profound transformation of society, which greatly affected women's lives. In contrast to what happened in other societies, at that moment, women in Turkey did not have to form well-defined organisations so that they could fight for political rights. Between 1923 and 1935, the Turkish state implemented a series of regulations guaranteeing several advances in women's legal status. This practice has been called state feminism (Tekeli 1990: 152), and it is characterised by a set of reforms in the areas of family, education, dress codes and political rights.

Under Mustafa Kemal Atatürk's charismatic influence, Turkey produced a completely new image of itself, actually trying to distance itself from its association with the Ottoman Empire. The caliphate was abolished in 1924, leaving all religious activities and institutions under state control, the capital was transferred from historic Istanbul to Ankara, and a series of measures were introduced from governmental agencies above to the population. The 'new woman, the republican woman, a model created by the Turkish state, began to be encouraged to attend university, to obtain professional qualifications and, then, to contribute to national development. A secular civil code was adopted in 1926 which gave men and women equal civil rights, polygamy was banned, and women could then ask for a divorce. In 1934, full suffrage was implemented; however, men were still officially recognised as the breadwinners, and women still needed permission from their husbands to work outside home (White 2003: 151).

Despite legal advances, Turkish women authors have recently been criticising these developments, highlighting their contradictions. These questions concern, for example, 
the lack of women's agency at that time. It was expected that this new woman, representing the modern Turkish state, would behave according to what was defined by the state itself; women were regarded as guardians of these reforms and of 'progress' (Durakbasa 1998: 142, cited in Ecevit 2007: 191), in this sense, they could not challenge the identity attributed to them. It has even been argued that Turkish women generally accepted and internalised the state discourse. In parallel, there was a state whose authoritarian nature, given the one-party political system, took advantage of this new model of women to create and reproduce a uniform citizenship (Kandiyoti 1991: 43), which made it difficult to create independent women's organisations. In this respect, the state stands as the guarantor of women's rights and appropriates this space of struggle. For Tekeli (1990: 153), this passive attitude among Turkish women in not engaging in political activities to influence state decisions continued after the transition to a multiparty system in 1946, and this scenario remained the same until the end of the 1980s, at least.

Moreover, this model role for women created by the Turkish Republic corresponded to the urban bourgeoisie (White 2003: 147). Around 20\% of the population lived in urban areas at that time, and it was not until the 1950s that rural-urban migration began, which means that this 'republican, modern and secular woman' who enjoyed a set of rights and opportunities corresponded to a very limited part of the population. According to White (2003), women's lives in less central areas, when compared to Istanbul and Ankara, were quite different. It took decades until state reforms, through its institutions, could reach regions farther from those urban areas where the elements of the modern and secular Turkish nation were formed. Women in rural areas lived a different reality. They performed heavy physical work in the countryside, mostly unpaid, since they were in family-owned initiatives. Thus, they did not have the same opportunities regarding access to education and employment outside the home, which did not contribute to the weakening of the material basis of patriarchal relations. ${ }^{4}$

The Kemalist reforms were not designed to transform gendered social roles constructed around unequal power relations between men and women but to achieve a political aim, the construction of the modern Turkish state. According to Ince, Yarali and Özsel (2009: 541), a process that began in the first years of the Republic and that continued until the 1980s was the non-consideration of women as autonomous actors with their own rights. These rights were granted only to Turkish women and justified based on the interests of the whole society. The status of Turkish women in the formation of the state assumes, thus, a nationalist mission (Arat 1997: 100).

In the early years of the Republic, most of the Kurdish population lived in the southeastern part of the country, in isolated, mountainous and poor regions near the border with Iran, Iraq and Syria. Migration to urban areas in Turkey only occurred from the 1950 s on, so it is possible to argue that in those early decades, the vast majority of Kurdish women did not have access to this set of legal measures that transformed women's lives in urban areas. It is also possible that a proportion of Kurdish women, albeit limited, were influenced by these measures. But for that, it was necessary for their families to live in better socioeconomic conditions, to decide to adopt a Turkish identity to some extent, and live in these urban centres or circulate through them easily. 
With the appropriation of Turkish women's space of struggle by the state, it is evident that their autonomous political initiatives were discouraged in the early years of the Republic, a scenario that remains almost untouched for the coming decades. Furthermore, state control of women's organisations that emerged, and the fact that Turkish women have largely internalised the nationalist discourse of the state, created a context of great difficulty for the construction of a 'sisterhood' between Turkish and Kurdish women. Attempts to create solidarity between Kurdish and Turkish women, based on the argument that because they were women, they would share a common point, did not find fertile ground until the 1980s. The argument about the common ground is still true, that is, Kurdish and Turkish women shared gender subordination, but this is only a part of their lives; ethnicity in a nationalist state such as Turkey has a profound impact on people's life experiences.

It was only in the 1980s that a liberal feminist movement began to appear. This emerging voice breaks the kind of consensus that there was no right to fight for, which was based on the belief that the state had already emancipated women. This is the generation that sees the contradictions and criticises Kemalist reforms. From the 1990s on, these groups began to institutionalise, trying to influence state decisions. Concurrently, Kurdish women's political activism also gains prominence, as they began to participate in large public mobilisations, addressing their claims to the state, as well as engaging in nationalist organisations such as the PKK, in a number of political groups, human rights and women's rights groups, and to organise women's groups within the pro-Kurdish parties that emerged.

Despite the notorious developments since the 1980s, with respect to the independence of the women's movement in its relations with the state, feminism in Turkey still had significant problems. In the relationship of the Turkish feminist movement with Kurdish women, in the 1990s, there is what Yüksel (2003) calls blindness towards the latter. Turkish feminism failed to realise the specificities of Kurdish women's lives, which was related to a set of factors, but in this specific context, especially to their ethnicity. According to Ilkkaracan (1997: 21, cited in Mojab 2001: 6), from the 'Women for Women's Human Rights:'

The Turkish women's movement has also failed to bring a substantial critical approach to militarism and the on-going war in Eastern and South-eastern Turkey, the rise of a new nationalism and the official discourses of the state on Turkish identity, in which it claims that all the citizens living within the boundaries of Turkey are 'Turks'. Aside from some initiatives condemning racism, there is almost no effort to solidarize and engage in networking with Kurdish women to bring solutions to their specific problems.

It was imperative that the intersections of power relations informing Kurdish women's lives were placed at the core of the debate. The difficulty on the part of feminism in Turkey in the 1990s of seeing and then treating Kurdish women's realities, which are marked by their positioning in an ethnic community, is, thus, an element that creates a motivation and emphasises the need to build an autonomously organised Kurdish women's move- 
ment. In this sense, there is the deconstruction of the political actor, 'the woman', incorporated by Turkish feminism, and an incentive to build autonomous spaces. For Kurdish women in the PKK, a space where the clash with the elements that made up the 'Turkish nation' has always been greater due to the guerrilla war against the state, such a stimulus is perceived even more intensively. The blindness to ethnicity meant, consequently, blindness to the material and symbolic violence suffered by these women in their relations with the state. This also meant blindness to the specificities of the unequal gender relations reproduced within Kurdish society.

\section{Understanding Kurdish women's vulnerability}

It is important to provide information related to the insecurity of the Kurdish community in Turkey that is closely linked to the formation of the nation-state. Right after the founding of the Republic, the regulations that characterise the Kemalist regime's strategic move towards the Kurdish population could already be noticed, with the prohibition of the use of Kurdish, including in schools. In 1925, only 215 out of 4,875 schools in Turkey were located in Kurdistan, and without the Kurdish-medium schools, the numbers of Kurds who could have access to education was considerably limited (McDowall 2007: 192). According to McDowall, it is in this process that the Turkish state adopts a racist policy to exclude all non-Turkish elements from society.

More recently, based on the 1993 Turkish Demographic and Health Survey (Ministry of Health [Turkey] 1994), Içduygu, Romano and Sirkeci (1999: 1002) observed some indicators that characterise the disparities in development rates between eastern Turkey, including the south-eastern part of the country, where there is a concentration of about $70 \%$ of the Kurdish population, ${ }^{5}$ and the western part of the country, where the capital and cities such as Istanbul and Izmir are located:

The western region's per-capita gross national product was US\$ 2,000 , the eastern region's was US\$700; the western region's total fertility rate was 2 , the eastern region's was over 4 ; the western infant mortality rate was 43 , the eastern region's was 60 ; the western region's illiteracy rate was 14 , the eastern region's was 26 ; the western region's number of health personnel per 1,000 people was 3.2, the eastern region's was 2 .

Additionally, the eastern/south-eastern part of Turkey lived with a state of emergency between 1987 and 2002 at least (Bozgan 2016: 154), with approximately 35,000 people imprisoned and killed since the early 1980s. In this context, schools were closed in 3,000 villages, leaving about 1500000 children deprived of education, more than 3,000 villages were evacuated, and more than 3000000 people have left the region in the last 20 years, voluntarily or not (Içduygu, Romano and Sirkeci 1999: 1002-1003). Between 1924 and 1938, of 18 Turkish army operations, only one occurred outside Kurdish regions, and after 1945, besides the Korean War between 1949 and 1952, and the invasion of Cyprus in 1974, the army continued to be used only against the Kurds (McDowall 2007: 198). 
The numbers on education are revealing. Although primary education is compulsory in Turkey, according to Içduygu, Romano and Sirkeci (1999: 1003), only 61\% of Kurdish men and $38 \%$ of Kurdish women have finished primary education. And, in the eastern part of the country, two out of five Kurdish men and two out of three Kurdish women have never attended school. Many Kurdish men learn to speak Turkish only when they join the military. The lack of education and Turkish proficiency considerably limit the Kurd's socioeconomic opportunities, and Kurdish women's in particular.

In this regard, Çağlayan (2007, cited in Bozgan 2016: 153) argues that the language barrier was one of the major difficulties faced by Kurdish women when they migrated to urban areas in Turkey. Since the education rates are lower among Kurdish women, in comparison to both the western population in Turkey and the male population of Kurds in the eastern region, it is not difficult to conclude that even in the search for better life conditions in other regions - when the migration was voluntary - many Kurdish women experienced these processes differently from men in their communities and, undoubtedly, faced greater difficulties. Here, we cannot forget the effects of the region's and Kurdish society's patriarchal structures on women's lives, especially on those living in rural areas. In a society dominated by men, there's only space for women to limit themselves to the social roles assigned to them. It is also against these structures that Kurdish women organise, as we will argue later in this paper.

The impact of these processes on Kurdish women's lives, specifically on those living in the south-east of the country and belonging to less favoured social classes, creates a scenario in which this insecurity is aggravated. According to Yuval-Davis (2004: 22), although gender, ethnicity and class have different ontological bases and distinct discourses, they intertwine in such a way as to establish complex social relations. What these issues reveal, therefore is that being Kurdish woman in the socioeconomic contexts described above fundamentally reflects in these women's life experience. Kurdish women's life experience is different from that of Turkish citizens, whether men or women, and even from Kurdish men's experience.

\section{Contextualizing Kurdish struggle: within and beyond nationalism}

Women's intense mobilisation in the DFNS is part of a political project that has become possible in the context of the aggravation of the Syrian Civil War. In mid-2012, the Syrian Levant began a process of militarisation, with the opposition organising to respond with weapons to the regime's violent attempts to suppress the protests, in addition to the growing threat of Jihadist groups. Concurrently, in the context of organisation of the groups opposed to the Syrian Government, the Arab opposition was increasingly expressing its dissatisfaction with the Kurdish claims in case of a post-Assad Syria.

In this process, Kurdish parties, organisations and intellectuals were beginning to turn to the Kurdish regional context, gradually distancing themselves from the conflict and aiming to develop their own political project and protect the Kurdish population from the Levant, which was beginning to become embroiled in a civil war (Allsopp 2014: 206). Meanwhile, the government and its military forces, faced with the violent escalation of the 
conflict, began to focus on more central regions of the country, where the opposition was more active. This was creating a power vacuum in the Kurdish regions in Northern Syria near the border with Turkey, which was quickly becoming occupied by Kurdish political groups.

The Democratic Union Party (PYD, acronym in Kurdish) is one of the organisations that has been contributing to the construction of the DFNS, and its importance is due to the fact that it has initiated, together with other activists, the political project of Democratic Confederalism idealised by Abdullah Öcalan. He is one of the founders and the leader of the PKK, who, since its formation, has advocated a resolution for the Kurdish Question aligned with the construction of an independent Kurdish state. But more recently, Öcalan has been proposing something different, this time, criticising the form of state organisation.

The Kurdistan Workers' Party, PKK, created in 1978 in Turkey, with Marxist-Leninist inspiration, advocated the formation of an independent Kurdish state. The group had a woman as one of its founders, Sakine Cansiz, widely recognised for her resistance while she was in prison and for the debates she developed from a gender perspective in the movement (Tax 2016: 133-136). Within a short time, the group was able to organise a guerrilla war against the Turkish state, and it captured its full attention after 1984. At that time, the PKK was able to exercise great influence in the south-east of Turkey, in many cases establishing a parallel government and challenging power in Ankara. According to Imset (1992: 31, cited in Romano 2006: 88-89), the group succeeded several times at establishing a local authority, filling a space that was often not occupied by the state. The PKK remained active in the 1980s and 1990s, but, in 1999, when Öcalan was arrested, the group started a profound process of ideological re-evaluation, transforming its agency and aims.

Rojava, comprising the three cantons of Afrin, Kobane and Cizire, declared autonomy in January $2014,{ }^{6}$ starting its own administrative and political process and distancing itself from the Syrian conflict. This thus emerges as an opportunity to put into practice a project that has been developing since the early 2000s, but whose roots date back thirty years. The ideas advocated by Öcalan, therefore, do not emerge from a vacuum, and the current developments in Northern Syria are not instantaneous, arising naturally from this historical moment, but reflect a long political process designed by many actors, and as this paper argues, they bear the great influence of Kurdish women.

The project of Democratic Confederalism introduces a central criticism of three components of the current organisation of society, namely, the nation-state, capitalism and patriarchy, together entitled 'capitalist modernity.' Thinking about this new project means, therefore, reflecting on alternatives to these elements. In this context, an independent Kurdish state ceases to be the aim. And the defence of the development and recognition of a plural society that organises itself based on democratic principles (Graeber 2014) gains importance. A set of local assemblies and councils have arisen at various levels of social life, from the most basic ones in the communes to the level where all the districts are put together, and whose purpose is to encourage the participation of people in the DFNS. In developing this project, two principles are central: so-called democratic autonomy, related to the self-governing power of the individuals in their communities (Öcalan 2016: 24); 
and a system based on this self-government exercised from below by a set of communities in a confederate mode (Öcalan 2011: 33). Therefore, what this experiment has been proposing is the construction of a model of basic and direct democracy in all decisionmaking processes.

Reflections on the unequal power relations that constitute gender relations are a fundamental topic for the construction of this political project, and this is where the criticism of patriarchy lies, ${ }^{7}$ which is considered a constitutive part of the nation-state structures. Öcalan argues (2011: 16) that the development of the nation-state occurs through the instrumentalisation of women in a practice where women aren't considered real political actors. This occurs, for example, through their exploitation as a reserve of cheap labour and as an instrument for the biological reproduction of this structure. In this sense, the exploitation of women is one of the deepest and most disguised social issues of the state and it is also related to the capitalist mode of production. 'Capitalism and nation-state denote the most institutionalized dominant male' (Öcalan 2016: 24).

In Women and Revolution: A Framework for Analysis, Mary Ann Tetrault (1992: 103) argues that women were always perceived as being biologically bound to human reproduction and this kept them in their homes, away from the domains of public life and embedded in the private subsistence economy of household. One of the strongest and most important disturbances provoked by Kurdish women in the modern political imaginary in which western society is embedded is the normative disruption of women's social role being defined by their reproductive capability. Once these women decide to join other women in armed struggle, they are somehow denying the normative biological role historically attributed to them and taking part in the revolution as agents like men.

Tetrault (1992: 112) argues that all states rest on a foundation consisting of gender hierarchy as well as class stratification and that the subordination of women is intimately connected to the emergence of the state. Moreover, she claims that, for a revolution to be potentially effective, it has to challenge state-based regimes in order to liberate women from men, as well as men from one another. Otherwise, if revolutions result in the strengthening of state institutions, the subordination of women will still be structurally favoured.

Following Tetrault's statement, we argue that the involvement of Kurdish women in the DFNS not only represents a gender hierarchy disruption but is, above all, a meaningful effort to turn women into agents of the revolution itself in order to constrain state power and not to be only passive individuals subsumed into male political participation. Thus, if modern state formation results necessarily in the repression of women, the revolutionary transformations in the DFNS are not able to liberate women unless it eliminates or constrains state power with all its male-based political domains.

Öcalan's writings, however, necessarily reflect debates developed by Kurdish women within the organisation, questioning gender inequalities reproduced in their communities and even in the Party. Indeed, the new element in this context is a women's movement that places such questions at the core of this project for autonomy, and which has become one of the foundations for the DFNS experiment. In this regard: 
The women's movement Yekîtiya Star ${ }^{8}$ is autonomously organized in all walks of life, from defense to economy to education to health. Autonomous women's councils exist parallel to the people's councils and can veto the latter's decisions. Men committing violence against women are not supposed to be part of the administration. Genderbased discrimination, forced marriages, domestic violence, honor killings, polygamy, child marriage, and bride price are criminalized. Many non-Kurdish women, especially Arabs and Assyrians, join the armed ranks and administration in Rojava and are encouraged to organize autonomously as well. In all spheres, including the internal security forces (asayish) and the People's Defense Units YPG and Women's Defense Units YPJ, gender equality is a central part of education and training (Dirik 2015).

These questions also reflect the arguments put forward by theorists in the social and political sciences. The analysis of how gender relations are instrumentalised by this fundamental political unit of the international system, the nation-state, may be found, for example, in feminist criticisms of nationalist movements and even of the Social Contract. What is noticed, therefore, is that the reflections brought by Öcalan, which centrally contribute to the construction of society in the DFNS, are products of theoretical developments in many areas of knowledge, in addition to the historical development of Kurdish political claims, firstly with a nationalist character and currently incorporating a different mode.

Öcalan plays a central role as the leader of a political organisation that is quite important to the Kurdish nationalist struggle, but one must not be naive in thinking that Kurdish women have no responsibility in this process. Here, it is fundamental to reflect on how the trajectory of women's self-organisation in the nationalist struggle transforms the theory and praxis of Kurdish resistance.

The family, in this context, emerges as a political site of ultimate importance since it is within and through the family structures that transformations pushed by Kurdish women may affect women's roles as well as politics and the military economy as a whole. According to Tetrault, family structures may be great agents of revolutionary transformations, and they should be taken for granted in the changes of gender and class consciousness. The author argues that one of the most remarkable attributes of modern family structure is the insulation of family from the rest of the society, which sets women (relegated to the private domain) apart from demands on the state. Nonetheless:

In a society where the privatized family is the dominant form, one strategy for revolutionary moments is to create new civil structures to compensate for kinship and community networks that were inadvertently lost in the process of modernization or purposely destroyed by an authoritarian state (Tetrault 1992: 109).

Even though she asserts that the insulation of the family can be seen as 'a poor arena for political mobilization' (Tetrault 1992: 109), her theoretical formulations are really in- 
sightful. Since, for her, family can be regarded as 'the locus of the socialization that produces cosmological beliefs and economic and political structures', we could argue that Kurdish women's incidence in warfare affects the way modern family structures are reproduced and, then, produces impacts on the broader political structure. When Kurdish women leave their homes and decide to join other women at war they are not only leaving their family behind but most importantly they are leaving behind a whole civil structure deeply rooted in patterns of gender hierarchy which supports the state. Thus, Kurdish women as revolutionary agents may turn family structures into revolutionary cells and challenge the state directly.

Another way through which Kurdish women challenge the modern state is through the transformation of family from an authoritarian unit to an egalitarian one as a form of addressing multiple forms of autonomy and community. For Tetrault, modern macrostructures, such as the international system and the nation-state, are based firmly on this pattern of dominance and submission and are supported by the illusion that dominance rests on universal and exclusive values. So, once Kurdish women offer other ways of being organised within society, either militarily or politically, they offer ways of political organisation that do not rely on such values.

Although the Kurdish women's movement was inspired by Öcalan's political leadership, the development and advance of these women's self-organisation around militarised and active units disrupt the boundaries within which nationalism has been thought among these actors. The trajectory of Kurdish women has been to challenge notions that constitute the foundational boundaries of the nation-state and the base of the international system. They point towards the limits of a political action within a nationalist framework and open up ways to rethink the conditions of possibility for living in a political community which does not reinforce the violence linked to its male-based structure.

\section{The encounter with the Party's comrades, an encounter with (the) violence}

It is in this scenario that the expressive participation of women in the PKK is born. According to Aliza Marcus (2007), in the 1980s, the presence of women was not very significant yet, since at that time, the PKK operated mainly in rural areas, where Kurdish women were prohibited to walk alone in the streets, which made the militants' approach difficult. Since 1989, as the Party began to develop co-optation strategies in cities and universities, as well as engaging in political publishing activities, women's participation grew. Women's involvement in support work in the Party offices was more easily accepted by family members than their joining the armed groups, reflecting the position these women held within Kurdish community.

Due to the increasing number of women, including those who have begun to take up arms, occupying positions connected to what societies construct as attributes of 'masculinity' and, thus, openly challenging the functions assigned to them in social life, various contradictions were noticed. There were men who did not accept women as companions 
of the same struggle and their active involvement in the organisation and who remained attached to their privileged positions of power (Marburg 1997, cited in Tax 2016: 136). The reaction of the Kurdish civilian population to women's presence in the guerrilla forces is something that also gains attention:

Kurdish villagers often were surprised to discover women among the gun-toting rebels who descended on the villages at night to make propaganda and collect supplies. Aysel Curukkaya, who rejoined the rebels in 1986 after her release from prison, recalled that village women could not believe another woman had gone to the mountains to fight. One young girl insisted on running her hands under Curukkaya's shirt and screamed in surprise when she realized Curukkaya really had breasts. Men, on the other hand, were shamed into action when they realized that women also were fighting (Marcus 2007: 172).

This passage from Marcus's book on the PKK is enlightening, since it reveals nuances in the patriarchal relations in which some of the Kurdish women are embedded. This context is evident with the surprise that arises in the child and in the adults from the village when they see women taking up arms to defend the nationalist cause, making political propaganda, and contributing in different ways to the construction of this project. This reaction was so unique that the child was surprised to find out, physically, that this was a woman in the guerrilla forces occupying a space that wasn't the domestic one (usually under the tutelage of relatives, especially of male relatives), occupying spaces outside home and a position that is usually occupied by their fathers, brothers, husbands and sons. In addition, men who fought alongside women in the PKK, who shared the same space of political mobilisation, felt embarrassed and morally upset when they saw women fighting at their side.

Some authors have discussed the importance of nationalist movements in relation to women's political mobilisation (Yuval-Davis 2004; Jayawardena 1986; Enloe 2014), and despite the contradictions that may arise from these contacts, such as the instrumentalisation of women in nationalist narratives, these organisations have given them the opportunity to create identities other than those built by marriage and motherhood, restricted to the private sphere of the family. Personal motivations have a great influence in the construction of this participation, when Kurdish women saw their entry to the PKK as a form of emancipation from the social constraints they faced in the family daily life, and as a way of being recognised and respected in their communities. In the Party spaces, women have found new functions not related to family life, where the unequal gender relations and the consequent subjugation of their conditions as women continue to be widely reproduced.

According to Yuval-Davis (2004: 178), interviews with women who served as soldiers, especially those who were part of national liberation organisations, have revealed that many of them sought to escape intolerable personal situations caused by colonial forces and those loyal to them or even caused by their own family. In these military organisations, women were able to create new identities and skills and achieve social positions 
considered respectable, as well as to fight for causes they believed in (Yuval-Davis 2004). For Sancar (1997, cited in Bozgan 2016: 153), gender roles have also undergone transformations with the participation of women in these movements. When the PKK's nationalist struggle arrived in Kurdish households, engaging different family members, traditional roles played by women as mothers, wives, sisters and daughters were also politicised, gaining new lines.

For the Kurdish movement that has organised around Democratic Confederalism, the family is at the same time one of its greatest obstacles and an element that plays a fundamental role (Öcalan 2013). The way in which the patriarchal family is organised removes women from the political, intellectual, social and economic arenas, restricting them to the domestic sphere, and it is in this context that a call for a deep revision of the family and the power relations that are established in this space emerges. When Kurdish women abandon their assigned roles and engage with the nationalist movement and different political organisations and become guerrillas, for example, they respond to that call. This is where the process of revising this old family structure begins.

In her analysis of social contract theories, Carole Pateman (1988) argues that the pact established in the context of these theories is social as well as sexual, insofar as it is patriarchal, that is, the contract establishes men's political right over women, while also establishing men's access to women's bodies. The social contract, which tells a story about freedom when the inhabitants of the state of nature exchange their insecurity derived from natural liberty for civil liberty and state protection, is also a story of women's subjugation.

One of the reasons that led to the omission of this interface of the pact is a superficial approach that, according to Pateman (1988: 3), ignores the creation of two separate, but inseparable, spheres in civil society: on the one hand, the public sphere, seen as a place of exercise of civil liberty and inhabited by men, and on the other, the private one, politically irrelevant and women's place par excellence. It is possible to argue that Kurdish women joining the PKK challenge these boundaries through a double movement. They enter into the public sphere, considered politically relevant and from which they were historically excluded, while they politically resignify the private sphere, the space to which they were relegated. And in line with the feminist insight 'the personal is political,' Kurdish women bring to the core of the debate for self-determination their experiences as women, while denouncing the power relations within the family.

Hejîn, a young woman who left home over four years ago, comes from a poor family in a neighbouring province where she was herding sheep instead of going to school. She jokes about her broken Turkish, but says she learned to read and write in the mountain camps of the PKK. 'I learned about many things there', she recalls. 'For the first time I experienced an egalitarian lifestyle. Back at home I never dared to speak up with anyone, especially not with men. In our organization, we share all the tasks equally. It is considered deeply shameful to wash another man's socks, for example, and we all cook together (Letsch 2015). 
Hejîn's speech has an unprecedented significance, for many Kurdish women, especially those who lived in rural areas, had difficulties attending school or even did not attend it, and faced the possibility of arranged marriages. In this context, Kurdish women begin to see the nationalist struggle as an opportunity to build alternative paths to their own lives, both as individuals and as important actors in their communities. After all, their purpose was to strengthen the nationalist struggle and to support the resistance to the material and symbolic violence carried out by the Turkish state. In this process of physical and psychological empowerment, it is not difficult to imagine that many women engaged in the PKK since its foundation have escaped forced marriages, honour killings, and many other situations that conform to the patriarchal practices of Kurdish society.

In 1993, about a third of the PKK armed forces were women (Marcus 2007: 172). The growing participation in the Party organisations, and especially in the guerrilla forces, has given rise to what Melike Yasar (2015), from the Kurdish women's movement, calls a patriarchal paradox within the movement. Men in the guerrilla forces declared that the resistance in the mountains was not for women and that, therefore, they should return home and be part of civil resistance. Fighting with guns in the guerrilla forces was regarded as a men's job, says Fadile Yildirim (2012), also an activist in the Kurdish women's movement.

The fact that males make up the majority of combatants in military organisations throughout history and in national or guerrilla armed forces, for example, is not a 'natural' process, but it is built based on gender relations and, thereby, according to Enloe (2000: 235), ideas about masculinity have been closely connected to militarism. For Cockburn (2004: 34), despite the varied motivations that encourage men's participation in military organisations, their positioning in the patriarchal systems and their masculinity-related identities sustain this practice, with many versions of masculinity in different cultures built from the practice of fighting. In these narratives, it is generally for the safety and honour of wives and daughters that men go to war.

The socially constructed multiple dimensions of masculinity create the multiple modes of power that circulate in the domain we call the state, as argued by Wendy Brown (1995). Among four different modalities of state power in which we can identify the masculine character of the state, Brown stresses the prerogative dimension, which defines men as those who are in the position to protect, in contrast to women and sons, regarded as those who are in need of protection. This gender hierarchy endows the multiple domains of the state with a certain institutionalised protection linked to a paternalism which informs the prerogative to protect and to be protected. For Brown, the institutionalised protection and paternalism are entangled as part of a legacy from the theory of social contract in which 'natural freedom' is exchange for collective and individual security ensured by the state, as also pointed out by Pateman.

In the case of Kurdish women, their involvement in guerrilla warfare disturbs what Brown (1995: 187) calls 'patrimonial authority', the physical capacity to defend households with rightless women. In this sense, Kurdish women's disruption of gender roles within society comes along with putting into question all male-based structure of the state in which the masculine figure is the only one capable of providing security and protection. 
It thus challenges the deepest foundations over which our modern political imaginary is constructed and prompts us to rethink the terms within which political life is intimately apprehended alongside constructions around notions of masculinity/femininity, strong/ weak, public/private and so on.

Kurdish women, by joining the PKK guerrilla forces, made the hegemonic notions of masculinity and femininity confusing. And as it happens, when women are incorporated into the military as soldiers, this process creates prejudice and fear on the part of men. In an attempt to resignify their functions in society, Kurdish women and their female bodies in the guerrilla forces thus challenged the privileged power positions occupied by men in the spaces considered to be of political relevance.

The reaction to women joining the military organisations is also located in the context of nationalist discourses, which invariably incorporate these notions of socially constructed masculinity and femininity. Generally speaking, nationalist narratives establish women $^{9}$ and children as individuals in need of protection along with the territory, and men as individuals responsible for providing such protection. When Kurdish women join the PKK, leaving their homes and becoming politically active, they also become part of the protective force - whether of Kurdistan or Kurdish civilians - along with men. They become an active part of the discourse of national construction that has been historically characterised by male agency. In this way, the political difference between men and women that in the social contract theories consists in a direct conversion of sexual difference (Pateman 1988: 6) is destabilised. Furthermore, there is the possibility of subversion of the passivity function attributed to femininity ideals that support national constructions (Enloe 2014: 351).

\section{It is not about beautiful souls: disrupting the traditional use of violence}

The encounter with the PKK companions, as Yildirim (2012) argues, made Kurdish women come to realise that they were not in the same position as their male fellows, even in the struggle for self-determination. For Dirik (2014), Kurdish women perceived themselves especially affected in the context of the Turkish state, considering the process of ethnic discrimination and life socioeconomic conditions. Additionally, they were disadvantaged, even within their communities and families, due to the patriarchal relations. These different locations, both in the larger picture of a Turkish national society and in localised Kurdish backgrounds, are reflected in Kurdish women's life experience.

In the 1990s, the perception that unequal gender relations continued to be reproduced within the movement made Kurdish women from the PKK, though still affiliated with the nationalist organisation, begin to advocate the importance of building autonomous spaces for struggle to ensure that women's rights, as well as their experiences and knowledge, not be compromised. This exercise is related to intersectionality as a critical praxis, in Patricia Hill Collins's terms (2015). It is impossible to develop actions to challenge these social problems having as background a context where differences are not considered as produced and reproduced in scenarios marked by interconnected systems 
of oppression. It was necessary, therefore, to destabilise the unity of the political actor created by the nationalist organisation. Kurdish men and women were affected differently by the policies of the Turkish state, they experienced diverse social relations within Kurdish communities, and the same was also reproduced in the PKK.

In 1993, the first women-only units were formed within the guerrilla forces, and in 1995, in the First Kurdistan Women's Liberation Congress, the first army is created in the PKK composed only of women, the Kurdistan Free Women's Union, later called YJA-Star (Güneser 2015: 61-62), and with women at its command (Çağlayan 2012). The women's militarisation was seen as a process that happened beyond purposes related to combat, also encompassing social, political and cultural spheres. As in the guerrilla spaces, women also organised themselves ideologically and politically. The formation of an autonomous women's army may be considered the beginning of the construction of other autonomous spaces. The central aim was to create environments where women could develop themselves independently and freely, and place themselves into the movement, criticising and building it from their own perspectives, not as subsidiaries of a movement formed mainly by men and commanded by them (Beran 1995, cited in Tax 2016: 137). In this context, they also wanted to gain recognition of Kurdish society and the guerrilla forces.

Kurdish women's involvement in warfare deeply shakes the notions and practices on which the international system and the modern state were constructed. The history of the international system and international relations are strongly bound up with the widespread idea that western superpowers' use of force has been always legitimated in terms of a civilising mission. According to Tarak Barkawi and Mark Laffey (2006), the legitimate use of force by the West is intimately connected to a certain claim of rationality in which those who have already achieved modernity and have been endowed with western modern attributes, such as rationality, may be able to resort to the use of force. Following Pateman's theoretical framework on the social/sexual contract, if we take into account, according to what she argues, that women were historically regarded as the non-rational individuals and associated with the (state of) nature, Kurdish female active participation in warfare can be considered as a striking disruption of these notions about the legitimacy of the use of force and violence bound up with abstract, universal and rational claims.

The cleavage between those who are legitimate in their use of physical force or violence and those who are not is an essential character of international politics. The realist assumption that 'the strong do what they have the power to do and the weak accept what they have to accept' in the dialogue between Athenians and Melians from Thucydides's History of the Peloponnesian War (1972: 402) is part of the most fundamental basis of the modern international system. According to Barkawi and Laffey (2006), it is necessary to grasp the mutual constitution of core and periphery, and the interdependence upon imperial relations in order to reverse this conventional interpretation, which is a Eurocentric account of who is endowed with agency, rationality, power and morals.

Kurdish women's engagement in military life is a way of disturbing this so deeply rooted modern political imaginary and also a way of calling into question the 'weak and strong' ideals of legitimacy to bear arms. Beside the gendered disruption implied in their 
movement, they also put into question the monopoly of the legitimate use of violence. If we think in Fanonian terms, the use of violence in liberatory projects is the condition of possibility for emancipation. Nonetheless, unlike Frantz Fanon (2004), in the case of Kurdish women, their emancipatory struggle is not channelled in nationalist terms, they are not oriented towards a national liberation but rather their own liberation from the very sexist and oppressive structure of the nation-state. Kurdish women call into question the monopoly of the legitimate use of violence precisely inasmuch as they disturb the state as the only locus of political viability for the use of violence, and they displace the domain of violence from the state to their own hands.

For Kurdish women and the movement they are creating in Rojava, the international narrative of the 'legitimate use of violence' may be related to what they call self-defence. In this regard, self-defence is about mobilising ways to protect oneself from physical violence, but also from other forms of violence, such as symbolic and cultural ones (Üstündağ 2016: 199). All the autonomous spaces women create to organise themselves in Northern Syria are completely connected to this central idea. The example of Kurdish women's agency in the Syrian Democratic Forces, a military coalition made up of different groups in the region to fight Daesh in the historic liberation of Raqqa and consequently to weaken this terrorist group, represents not only the exercise of self-defence, but also a concrete questioning of the legitimacy of the use of force and violence.

\section{Conclusion}

In terms of historical development, the two encounters debated in this paper happen simultaneously. The plot unfolds in the 1990s and is marked by Kurdish women's perception of how power relations related to gender, ethnicity and class intersect, profoundly marking their lives. This process takes place in such way that even their male Party fellows, objects of the same material and symbolic violence carried out by the Turkish state, and even Turkish women, with whom Kurdish women shared gender violence, are unable to comprehend. Women's autonomous organisations in the PKK that begin to emerge at that moment are, therefore, intended to be a space to discuss such issues and to make contributions to Kurdish autonomy debates from these women's experiences.

What this paper argued is that in the process of realising their lives were marked by interconnected systems of oppression, Kurdish women not only strengthen their agency as they begin to organise autonomously, but also create challenges to some foundational boundaries of the modern state. When joining the PKK, Kurdish women disrupt the boundary between the public and private spheres and the limit related to who inhabits each of these spaces, since they force the occupation of the public sphere and politicise the private sphere of the family. In parallel, their bodies in the battlefield destabilise hegemonic notions of masculinity and femininity, connected, for example, to ideas of militarisation and passivity, respectively, on which the nation-state is built.

Women in Rojava are heirs of women in the PKK, and as such, their protagonism in this society cannot be understood without observing the paths that have already been 
taken by the struggle of those in the nationalist organisation. Women in the DFNS continue this movement, challenging patriarchal notions on which the imaginary of modern political community is constructed. This happens through the Women's Protection Unit, the YPJ, a women's military unit that has been appearing in newspapers all around the world, but also through other autonomous organisations in the cultural, economic and political areas, which permeate society as a whole. A model of co-leadership between men and women, a quota of gender representation in mixed institutions, academies and educational centres for women, and Jineology, the 'women's science', are all initiatives that have organised people in the DFNS around the idea that the liberation of society is only possible through women's liberation.

\section{Notes}

1. Here we have two examples of an online media approach towards the Kurdish women's struggle: Godden (2016) and Webb (2016).

2. The word Rojava means 'west' in Kurdish and it refers to the western part of what would be Kurdistan, in Syrian territory.

3. It is also important to remember that Öcalan, one of the founders and leader of the PKK in Turkey, took refuge for years in Syria, and a significant number of Kurds in Syria supported the Party and also joined its ranks.

4. The weakening of the material bases of patriarchal relations does not necessarily indicate the overcoming of these relations. The legal reforms of the Turkish state, for example, which granted rights to women, encouraging them to occupy the public space and work outside home, improved many women's material living conditions. However, in the private sphere, these unequal gender relations remained untouched. Therefore, patriarchal relations were not dissolved, only their material bases weakened.

5. This region is also less densely populated and has lower rates of industrialisation and socioeconomic development.

6. However, since 2012, the three cantons have been organising themselves based on Democratic Confederalism. In 2014, a sort of social charter created by groups of different ethnicities and religions was ratified. This document, which serves as a guide to the construction of this project of society, defends principals such as self-determination, plurality, gender equality, democratic participation and secularism, and it is built in consonance with Democratic Confederalism (Rojava Social Charter 2014).

7. For Öcalan (2013), the term 'patriarchy' refers to a system of domination exercised by men over women. The continuation of this system depends on a structure based on hierarchies that are reproduced throughout society. In this same context, Kurdish women in Rojava argue that patriarchy is constituted in opposition to a matriarchal society, which existed in the Monolithic Era.

8. In 2016, the organisation adopted the name Kongreya Star.

9. Considerations on gender need to be made taking into account power relations also connected to issues such as ethnicity, class, and religion, among others. Thus, the term 'woman' used both in reference to the woman in need of protection and those who may be the target of violence in times of conflict refers to a specific woman's profile. 


\section{References}

Allsopp, Harriet. 2014. The Kurds of Syria: Political Parties and Identity in the Middle East. London: I. B. Tauris.

Arat, Yesim. 1997. 'The project of modernity and women in Turkey' In Sibel Bozdogan and Ressat Kasaba (eds), Rethinking Modernity and National Identity in Turkey. Washington, DC: University of Washington Press, pp. 95-112.

Barkawi, Tarak and Mark Laffey. 2006. 'The Postcolonial Moment in security studies.' Review of International Studies 32 (2): 329-352.

Bozgan, Dilan. 2016. 'El Movimiento de Mujeres Kurdas en Turquía.' In Karina Bidaseca (ed), Genealogías críticas de la colonialidad en América Latina, África, Oriente. Cidade Autônoma de Buenos Aires: CLACSO, pp. 147-168.

Brown, Wendy. 1995. States of Injury. Princeton: Princeton University Press.

Çaglayan, Handan. 2012. 'From Kawa the Blacksmith to Ishtar the Goddess: Gender constructions in ideological political discourses of the Kurdish movement in post-1980 Turkey: Possibilities and limits.' European Journal of Turkish Studies (14): 1-27.

Cockburn, Cynthia. 2004. 'The continuum of violence: A gender perspective on war and peace.' In Wenona Giles and Jennifer Hyndman (eds), Sites of Violence: Gender and Conflict Zones. Los Angeles: University of California Press, pp. 24-44.

Collins, Patricia H. 2015. 'Intersectionality's definitional dilemmas.' Annual Review of Sociology (41): $1-20$.

Dirik, Dilar. 2014. 'Stateless democracy: How the Kurdish Women Movement Liberated Democracy from the State.' New World Summit Brussels [online]. 19-21 September. At https://vimeo. com/107639261 [Accessed on 13 February 2017].

. 2015. 'Feminism and the Kurdish freedom movement'. Kurdish Question [online]. 20 April. At http://kurdishquestion.com/oldarticle.php?aid=feminism-and-the-kurdish-freedom-movement [Accessed on 20 January 2016].

Ecevit, Yildiz. 2007. 'Women's rights, women's organizations, and the state.' In Zehra Kabasakal Arat (ed), Human Rights in Turkey. Chicago: University of Pennsylvania Press, pp. 187-201.

Enloe, Cynthia. 2000. Maneuvers: The International Politics of Militarizing Women's Lives. Los Angeles: University of California Press.

2014. Bananas, Beaches and Bases: Making Feminist Sense of International Politics. Berkeley: University of California Press.

Fanon, Frantz. 2004. The Wretched of the Earth. New York: Groove Press.

Godden, Maryse. 2016. 'Poster Girl Killed Fighting ISIS: Beautiful female fighter dubbed the Angelina Jolie of Kurdistan dies while battling ISIS in Syria,' The Sun [online], 7 September. At https:// www.thesun.co.uk/news/1743401/beautiful-female-fighter-dubbed-the-angelina-jolie-of-kurdistan-dies-while-battling-isis-in-syria/ [Accessed on 2 May 2016].

Graeber, David. 2014. 'Why is the world ignoring the revolutionary Kurds in Syria?' The Guardian [online]. 8 October. At https://www.theguardian.com/commentisfree/2014/oct/08/why-worldignoring-revolutionary-kurds-syria-isis [Accessed on 2 May 2016]. 
Güneser, Havin. 2015. 'Feminicide.' In Renee In der Maul and Jonas Staal (eds), New World Academy Reader No. 5: Stateless Democracy. Amsterdam: BAK, pp. 56-69.

Içduygu, Ahmet, David Romano and Ibrahim Sirkeci. 1999. 'The ethnic question in an environment of insecurity: The Kurds in Turkey.' Ethnic and Racial Studies 22 (6): 991-1010.

Ince, H O, A Yarali and D Özsel. 2009. 'Customary killings in Turkey and Turkish modernization.' Middle Eastern Studies 45 (4): 537-551.

Jayawardena, Kumari. 1986. Feminism and Nationalism in the Third World. London: Zed Books Ltd. Kandiyoti, Deniz. 1991. 'End of empire: Islam, nationalism and women in Turkey’. In Deniz Kandiyoti (ed), Women, Islam and the State. London: Macmillan Press, pp. 22-47.

Letsch, Constanze. 2015. 'Kurdish women pray for peace as fears of civil war in Turkey mount.' The Guardian [online]. 16 August. At https://www.theguardian.com/world/2015/aug/16/women-joinkurdish-rebel-ranks [Accessed on 20 February 2017].

Marcus, Aliza. 2007. Blood and Belief: The PKK and the Kurdish Fight for Independence. New York: New York University Press.

McDowall, David. 2007. A Modern History of the Kurds. New York: I. B. Tauris.

Mojab, Shahrzad. 2001. 'Introduction: The solitude of the stateless: Kurdish women at the margins of feminist knowledge.' In Shahrzad Mojab (ed), Women of a Non-State Nation: The Kurds. Costa Mesa: Mazda Publishers, pp. 1-22.

Öcalan, Abdullah. 2011. Democratic Confederalism. Cologne: International Initiative Edition. 2013. Liberating Life: Women's Revolution. Cologne: International Initiative Edition. 2016. Democratic Nation. Cologne: International Initiative Edition.

Pateman, Carole. 1988. The Sexual Contract. Cambridge: Polity.

Rojava Social Charter [Charter of the Social Contract], 29 January 2014. At https://peaceinkurdistancampaign.files.wordpress.com/2014/03/english-version_sc_revised-060314.pdf [Accessed on 2 May 2016].

Romano, David. 2006. The Kurdish Nationalist Movement: Opportunity, Mobilization, and Identity. New York: Cambridge University Press.

Said, Edward W. [1978] 1991. Orientalism: Western Conceptions of the Orient. London: Penguin Books.

Tax, Meredith. 2016. A Road Unforeseen: Women Fight the Islamic State. New York: Bellevue Literary Press.

Tekeli, Sirin. 1990. 'The meaning and limits of feminist ideology in Turkey' In Ferhunde Ozbay (ed), Women, Family and Social Change in Turkey. Bangkok: UNESCO, pp. 139-159.

Tetrault, Mary Ann. 1992. 'Women and revolution: a framework for analysis.' In V Spike Peterson, Gendered States: Feminist (Re)Visions of International Relations Theory. Boulder: Lynne Rienner, pp. 99-121.

Thucydides. 1972. History of the Peloponnesian War. London: Penguin.

Ministry of Health [Turkey]. 1994. Turkish Demographic and Health Survey 1993. Calverton: Macro International Inc. At https://dhsprogram.com/pubs/pdf/FR57/FR57.pdf [Accessed on 5 May 2016]. Üstündağ, Nazan. 2016. 'Self-defense as a revolutionary practice in Rojava, or How to unmake the state.' South Atlantic Quarterly 115 (1): 197-210. 
Webb, Sam. 2016. 'Female Kurd soldiers fighting ISIS explain why they wear lipstick and make-up on battlefield.' Mirror [online], 30 August. At https://www.mirror.co.uk/news/world-news/femalekurd-soldiers-fighting-isis-8732664 [Accessed on 5 May 2016].

White, Jenny B. 2003. 'State feminism, modernization and the Turkish republican women.' National Women's Studies Association Journal 15 (3): 145-159.

Yasar, Melike. 2015. 'La Revolución de las mujeres y el pueblo kurdo, Parte 1.' Kurdistan Desde el Sur [online]. At https://www.youtube.com/watch?v=z_mS5c3ojPM [Accessed on 10 December 2016].

Yildirim, Fadile. 2012. 'Woman and democracy: The Kurdish question and beyond.' New World Summit Berlin [online]. At https://vimeo.com/65049118 [Accessed on 13 January 2017].

Yüksel, Metin. 2003. Diversifying Feminism in Turkey in the 1990's. Master thesis, Bilkent University, Turkey.

Yuval-Davis, Nira. 2004. 'Gender, the nationalist imagination, war, and peace.' In Wenona Giles and Jennifer Hyndman (eds), Site of Violence: Gender and Conflict Zone. Los Angeles: University of California Press, pp. 170-189.

\section{About the authors}

Bruna Ferreira holds a master's degree in International Relations from Rio de Janeiro State University (UERJ), Rio de Janeiro, RJ, Brazil. Her master's thesis, at the same university, discusses the emergence of the women's autonomous organisation in the region known as Rojava, in Northern Syria, from the perspective of Intersectional Feminism and having as its background the Kurdish struggle for autonomy. In the last three years, she has been studying Kurdish women's struggles and how they relate to the project of Democratic Confederalism. Her research interests include women's studies, postcolonial studies, feminism, racism and critical theory on the nation-state.

Vinícius Santiago is a $\mathrm{PhD}$ candidate at the Institute of International Relations, Pontifical Catholic University of Rio de Janeiro (IRI/PUC-Rio), Rio de Janeiro, RJ, Brazil. In the master's programme at the same institute he developed a research project on the struggle for justice of mothers whose sons have been killed by military police in the slums of Rio and their public mobilisation against state violence. During the last three years, he has been engaged in fieldwork following mothers in order to understand their relations with the state against this background. His research interests include postcolonial studies, poststructuralism, gender, racism and violence. 


\section{Cerne da Resistência: Reconhecendo a Luta Interseccional no Movimento das Mulheres Curdas}

Resumo: O artigo aborda o movimento de mulheres na região conhecida pelos curdos como Rojava, no norte da Síria, cujo papel central na construção de um projeto político autônomo tem suas raízes na luta nacionalista curda, especificamente a organizada pelo Partido dos Trabalhadores Curdos, também conhecido como PPK na Turquia. Este estudo traz à tona reflexões sobre as relações de poder que atravessam a luta realizada por essas mulheres, que, por sua vez, são atravessadas pela interseção de gênero, etnia e classe, que alimenta e compõe a práxis critica desta luta organizada. A trajetória política das mulheres curdas será abordada através das contradições e ambiguidades que enfrentam quando enfrentam o desafio de tomar consciência de seu próprio lugar no contexto de um projeto político que teve inicialmente um caráter nacionalista e que começa a ganhar novos contornos. A presença da figura feminina em um contexto político de conflito armado confere a essas mulheres o papel de desafiar as fronteiras nas quais os elementos fundamentais da política internacional se baseiam, a saber, a fronteira entre as esferas pública e privada e os papeis de gênero desempenhados social e politicamente. O movimento de mulheres curdas em Rojava desestabiliza as fronteiras fundamentais do Estado-nação moderno, juntamente com as construções hegemônicas de masculinidade e feminilidade, o caráter militarizado da política, que são constitutivos do imaginário moderno da comunidade política.

Palavras-chave: Interseccionalidade; Mulheres Curdas; Rojava; Estado-nação; Movimento.

Received on 28 January 2018, and approved for publication on 28 August 2018. 